\title{
The variability of pollen concentrations at two stations in the city of Wroctaw in Poland
}

\author{
Daria Bilińska (iD) Maciej Kryza • Małgorzata Werner • Małgorzata Malkiewicz
}

Received: 16 May 2018/ Accepted: 30 January 2019/Published online: 14 February 2019

(C) The Author(s) 2019

\begin{abstract}
The aim of the study was to investigate the variability of Alnus and Corylus pollen concentrations at two stations located in the city of Wrocław, Poland-one at the city centre and the other $4 \mathrm{~km}$ from the city centre. Our goal was to compare measurements from these stations in relation to meteorology and land cover. We used Spearman's correlation coefficient to investigate any dependence between meteorological factors and pollen concentration. Additionally, to check the relation between the direction of inflow of air masses and pollen concentration, we calculated the backward trajectories using the HYSPLIT model. The results have shown that despite the short distance between the stations, the characteristic of the pollen season is different for both stations (i.a. date of start and end of pollen season, duration of the season). The Spearman's correlation coefficient between relative humidity and air temperature and pollen concentration was found to be statistically significant. The backward trajectories calculated with HYSPLIT suggested a different origin of air masses between stations for high-concentration episodes in the case of Alnus. Our study has shown that
\end{abstract}

D. Bilińska $(\bowtie) \cdot$ M. Kryza $\cdot$ M. Werner

Department of Climatology and Atmosphere Protection, University of Wroclaw, Wrocław, Poland

e-mail: daria.bilinska2@uwr.edu.pl

M. Malkiewicz

Institute of Geological Sciences, University of Wroclaw, Wrocław, Poland analysis of meteorological conditions and influence of air transport into pollen concentration makes it possible to ascertain the reasons for differences in pollen level at these two stations, both of which are located in the same climatological domain. The study also shows that the aerobiological condition may change significantly over a short distance, which is a major challenge, for example, for pollen emission, transport, and concentration modelling.

Keywords Pollen · HYSPLIT $\cdot$ Meteorological conditions $\cdot$ Back-trajectories

\section{Introduction}

Corylus (hazel) and Alnus (alder) are trees which release first pollen grains that are measured in the air of Poland each year (Puc and Kasprzyk 2013). According to research conducted by Rapiejko et al. (2007) in Poland, the first symptoms of allergy of sensitized people to these taxa appear in low concentrations of pollen: for hazel, the threshold value is 35 pollen grains per cubic meter of air (pollen grains $\mathrm{m}^{-3}$ ) and for alder 45 pollen grains $\mathrm{m}^{-3}$, whereas symptoms for all sensitized people are observed at slightly higher pollen concentration amounting to 80 pollen grains $\mathrm{m}^{-3}$ in the case of Corylus and 85 pollen grains $\mathrm{m}^{-3}$ in the case of Alnus. 
It is estimated that $11.1 \%$ of Polish citizens suffer from hazel allergies. In the case of alder, this number is slightly higher, reaching $11.6 \%$ (Samoliński et al. 2014).

The pollen season strongly depends on meteorology (Puc 2007; Puc and Kasprzyk 2013; Sofiev et al. 2013; Malkiewicz et al. 2016; Dąbrowska-Zapart et al. 2018) as well as the type of land cover (Myszkowska et al. 2010; Charalampopoulos et al. 2018). Air temperature, humidity, wind speed and direction influence the length and intensity of pollen release and concentration in the air (Nowosad et al. 2015). Precipitation and humidity affect pollen release very strongly — and after reaching certain threshold values, these factors may totally suppress pollen release (Sofiev et al. 2013). According to Helbig et al. (2004), the threshold value for Alnus and Corylus pollen, for parameterization of emission flux for relative humidity, is $60 \%$, while for parameterization of resuspension it is $85 \%$. Above these values, emission is limited or completely stopped. Early flowering anemophilous trees to burst their anthers requires special meteorological conditions like high temperature, low humidity and moderate wind speed (Efstathiou et al. 2011).

The correlation between meteorological factors and pollen concentration has been investigated, for example, by Piotrowska-Weryszko (2013), Puc et al. (2015), Dąbrowska-Zapart et al. (2018) and Majeed et al. (2018). Malkiewicz et al. (2016) stated that with regard to the presence of Alnus and Corylus pollen in the air, the greatest influence has thermal factor. According to Dabrowska-Zapart et al. (2018), except the temperature, their studies showed also a statistically significant correlation coefficient between the amount of alder pollen grains and the weather front type. Puc and Kasprzyk (2013) compared pollen concentration and the meteorology for two cities in Poland (Szczecin and Rzeszów). They found that variations between the cities can be large, especially at the start of the season wherein the shift of the start of the season between stations in year 2011 almost reached 31 days. These cities, however, represent different climatological regions-Szczecin is located close to the Baltic Sea, while Rzeszów is located c.a. $700 \mathrm{~km}$ SE of Szczecin, thus representing a more continental climate.

In this work, we focus on the Alnus and Corylus measurements gathered at two stations located in the city of Wrocław, SW Poland, at a distance of c.a. $4 \mathrm{~km}$, thus representing similar climatological conditions. The main aim of this work is to study the variability of pollen concentrations within the city of Wrocław by comparing the measurements gathered from two pollen stations located in this city with the meteorological conditions and land cover. One site is located close to the city centre and surrounded by urban development, while the other is c.a. $3.7 \mathrm{~km}$ straight line from the strict city centre and surrounded by parks. Despite the minimal distance between the two sites, remarkable differences in concentrations and beginning/end of the pollen seasons have been described.

\section{Materials and methods}

\subsection{Pollen concentration data}

Pollen data were collected between 2013 and 2014 at two sites in Wrocław (Poland). The first station is located in the city centre, on the roof of the Institute of Geological Sciences, University of Wrocław (henceforth "City station", $51^{\circ} 6^{\prime} 59^{\prime \prime} \mathrm{N}, 17^{\circ} 1^{\prime} 40^{\prime \prime} \mathrm{E}$ ) at a height of $20 \mathrm{~m}$ above ground level (Fig. 1). In the vicinity of the sampling site, there are dense urban built-up areas and scanty patches of greenery. From the south, the building is surrounded by an alley of plane trees, while several horse-chestnut trees and small birches grow to the north of the building (Malkiewicz et al. 2014).

The second sampler is located at the top of the 15-m-high tower at meteorological station of the Department of Climatology and Atmosphere Protection, University of Wrocław (henceforth, "Park station", $51^{\circ} 6^{\prime} 19^{\prime \prime} \mathrm{N}, 17^{\circ} 5^{\prime} 20^{\prime \prime} \mathrm{E}$ ) (Fig. 1). Near the station (around the $150 \mathrm{~m}$ straight line) is the biggest park in Wrocław (Park Szczytnicki), with a number of different tree genera, including alder and hazel. Airborne pollen counts at both sampling sites were gathered using a Burkard 7-day volumetric pollen trap (Hirst 1952) and analysed following the recommendations of the International Association for Aerobiology (Galán et al. 2014). Pollen grains are counted under a light microscope with 400 magnifications along four longitudinal transects. The results were expressed as the number of pollen grains per $\mathrm{m}^{3}$ of air as a daily mean value (pollen grains $\mathrm{m}^{-3}$ ) (Galán et al. 


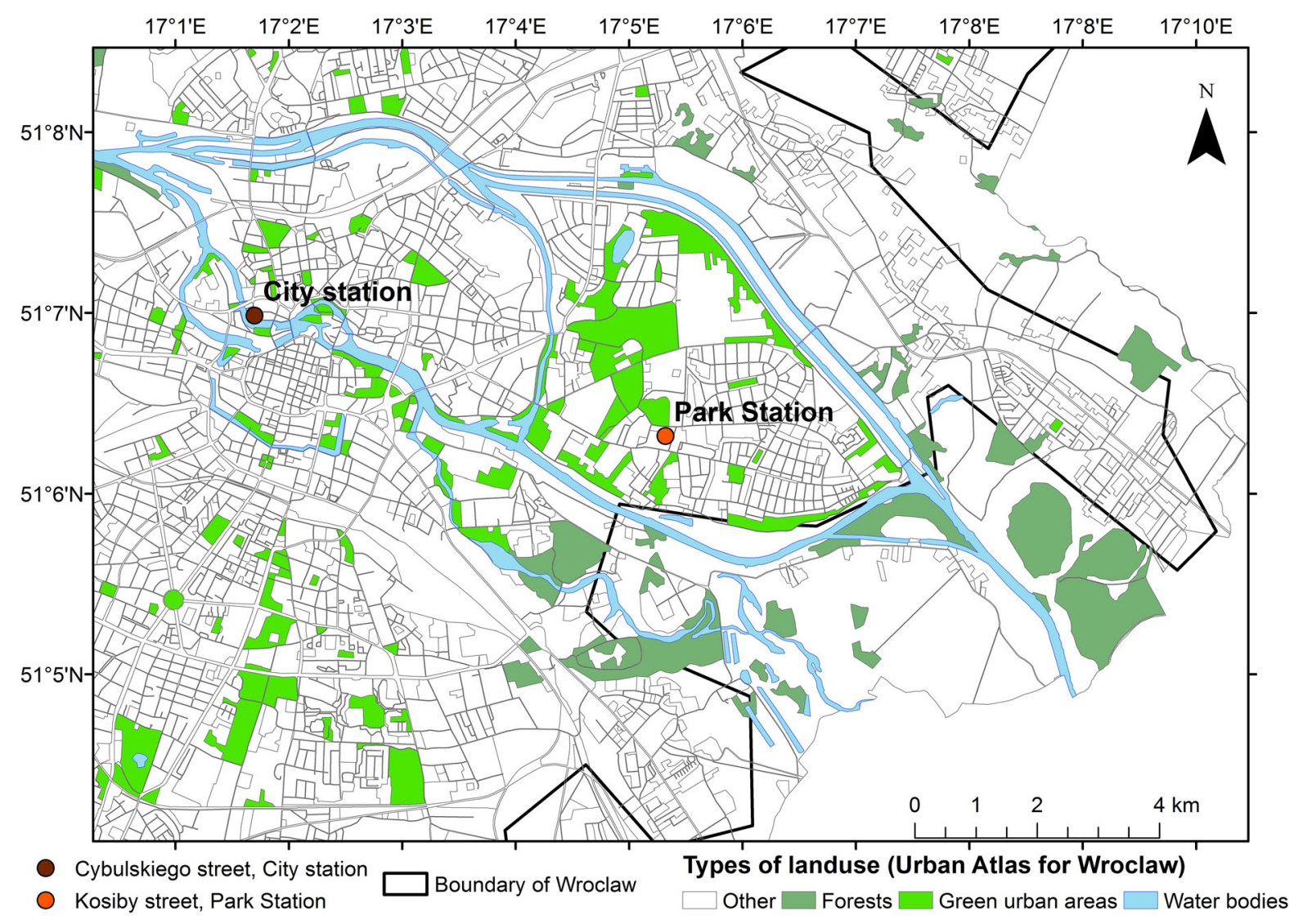

Fig. 1 Location and surrounding of two Wrocław stations-the City and the Park. Basemap-Urban Atlas 2012 (https://land. copernicus.eu/local/urban-atlas/urban-atlas-2012)

2017). Pollen concentrations of Corylus and Alnus are available for both stations for the years 2013 and 2014, and thus, these years were selected for further analysis. The start and end of the season were calculated using 95\% method which means that the start and end day was when the sum of daily mean concentrations of pollen reaches $2.5 \%$ and $97.5 \%$, respectively (Andersen 1991; Jato et al. 2006). The sum of daily pollen concentration during the whole season is here expressed as a Seasonal Pollen Integral (SPIn).

\subsection{Meteorological data}

Meteorological data were gathered at the Department of Climatology and Atmosphere Protection, University of Wrocław $\left(51^{\circ} 6^{\prime} 19^{\prime \prime} \mathrm{N}, 17^{\circ} 5^{\prime} 20^{\prime \prime} \mathrm{E}\right)$, which included: mean $\left[T\left({ }^{\circ} \mathrm{C}\right)\right]$, maximum $\left[T_{\max }\left({ }^{\circ} \mathrm{C}\right)\right]$ and minimum $\left[T_{\min }\left({ }^{\circ} \mathrm{C}\right)\right]$ temperature, mean and maximum relative humidity $\left[\mathrm{RH}, \mathrm{RH}_{\max }(\%)\right]$, the sum of precipitation $\left[R_{\text {sum }}(\mathrm{mm})\right]$, and daily mean and maximum intensity of precipitation $\left[R, R_{\max }(\mathrm{mm} / \mathrm{h})\right]$, wind speed $\left[V,\left(\mathrm{~m} \mathrm{~s}^{-1}\right)\right]$, solar radiation [diffuse $\left(\mathrm{SR}_{\mathrm{d}}\right)$ and total $\left.\left(\mathrm{SR}_{\mathrm{t}}\right)\right]$, and sunshine duration [SD $\left.(\mathrm{h})\right]$. The distance of meteorological station is $5 \mathrm{~m}$ from the Park station and about $4 \mathrm{~km}$ straight line from the City station.

\subsection{Statistical analysis}

We have used the Spearman's correlation coefficient to investigate the relationship between pollen concentration and meteorological data. The pollen data for the whole season from the two sampling sites were correlated with meteorological data from the same day and from the previous day. RStudio Desktop 1.1.383 was used for the calculations (RStudio Team 2015). RStudio: Integrated Development for R. RStudio, Inc., Boston, http://www.rstudio.com/). 


\subsection{The HYSPLIT model}

The Hybrid Single-Particle Lagrangian Integrated Trajectory Model (HYSPLIT) was created for i.a. diagnostic case studies or climatological analyses (Draxler and Hess 1998). Here, the HYSPLIT model was run in a trajectory mode. Meteorological data used for simulations were taken from the WRF model. The WRF model was configured with three nested domains having a spatial resolution of $12 \mathrm{~km} \times 12 \mathrm{~km}$ that covered Europe, $4 \mathrm{~km} \times 4 \mathrm{~km}$ (Poland), and $1.3 \mathrm{~km} \times 1.3 \mathrm{~km}$ (SW Poland). Vertically, all the domains have 35 levels. GFS FNL data, available every $6 \mathrm{~h}$, were used for meteorological initial and boundary conditions. Model configuration in terms of physical parameterization is provided by Kryza et al. (2017) and Ojrzyńska et al. (2017). For the HYSPLIT model, only the meteorological information from the innermost domain was used, as the high spatial and temporal resolutions were found to be important for the pollen transport studies, as reported earlier by Bilińska et al. (2017). The WRF model data were prepared for HYSPLIT using the arw2arl preprocessor.

The trajectories were calculated separately for the two sampling sites. We have used 72-h back-trajectories with a 2-h interval at two different altitudes (50 $\mathrm{m}$ and $1500 \mathrm{~m} \mathrm{agl}$ ). The trajectories were calculated for the years 2013 and 2014 for the whole pollen season of Corylus and Alnus and for pollen peaks as well. Apart from summarizing the entire pollen season, two kinds of grouping of high pollen concentration of Alnus were made. The first type ("high" group) covers days with the pollen concentration above 85 pollen grains $\mathrm{m}^{-3}$, which is a threshold value for the occurrence of allergy symptoms for all sensitized people with respect to alder (Rapiejko et al. 2007). The second type ("peak" group) reflects days with peaks of pollen concentration. Peak days were selected with the function "findPeaks" from the $\mathrm{R}$ statistical package, with a threshold value equalling to 85 pollen grains $\mathrm{m}^{-3}$ for Alnus. For Corylus, we found no days where the threshold value for all allergic people of 80 pollen grains $\mathrm{m}^{-3}$ was exceeded at both stations, and therefore, only the whole season is analysed further. For alder, both the "high" group and "peak" group were analysed.

The next step was to create frequency maps of trajectories in each grid cell. These maps were prepared for the two genera in both locations for $50 \mathrm{~m}$ and $1500 \mathrm{~m}$ in 2013 and 2014. The frequency was counted as the number of trajectories in each grid cell divided by the total number of trajectories. Maps were created with the use of ESRI ArcGIS 10.2.2 and the $\mathrm{R}$ statistical package. The correlation coefficient was used to quantify the differences between the spatial patterns of trajectories' frequency between the two measuring sites. The correlation was calculated by comparing each spatially corresponding grid (for the entire domain-SW Poland, $282 \times 222$ grids) as proposed by Kryza et al. (2011).

The maps of trajectories frequency were presented with the land cover map as a background, showing spatial distribution of Alnus and Corylus species (qualitative information provided after Bińkowska et al. 2013).

\section{Results}

\subsection{Corylus}

\subsubsection{Pollen season}

During the analysed period, higher concentrations of Corylus pollen were observed at the Park station. At this sampling site, the start and end of the season were observed earlier than at the City station. The differences were especially large in year 2013. At the Park station in 2013, the season started 25 days earlier than at the City station and also finished 5 days earlier. In 2014, it was 12 and 6 days, respectively. The duration of the seasons varied according to the years-the longest season was observed in 2013 at the Park station (71 days), while the shortest was at the City station in 2014 which lasted 46 days. The Seasonal Pollen Integral was at least two times higher at the Park station compared to the City station, with the highest value reached in 2014 (2292 pollen grains $\mathrm{m}^{-3}$ ). The highest maximum daily pollen concentration was measured in 2014 at the Park station (227 pollen grains $\mathrm{m}^{-3}$, 13 February) (Table 1).

The distribution of Corylus pollen shows strong day-to-day variability over the pollen season (Fig. 2). The peak values are higher at the Park station, which is located close to the pollen sources. Figure 2 shows that the main peaks occur at the same time for both stations. There is also a strong correlation in temporal 
Table 1 Characteristic of Corylus pollen season

\begin{tabular}{|c|c|c|c|c|}
\hline & \multicolumn{2}{|c|}{ Park station } & \multicolumn{2}{|c|}{ City station } \\
\hline & 2013 & 2014 & 2013 & 2014 \\
\hline Seasonal Pollen Integral (SPIn) & 1031 & 2292 & 774 & 559 \\
\hline The start of pollen season & 05.02 & 19.01 & 02.03 & 31.01 \\
\hline The end of pollen season & 16.04 & 11.03 & 21.04 & 17.03 \\
\hline Duration of pollen season (days) & 71 & 52 & 51 & 46 \\
\hline \multirow[t]{2}{*}{ Maximum pollen concentration (grains $\mathrm{m}^{-3}$ air)/date } & 148 & 227 & 96 & 39 \\
\hline & 06.03 & 13.02 & 06.03 & 15.02 \\
\hline
\end{tabular}

variations of pollen concentrations between the stations, reaching 0.78 and 0.88 for the year 2014 and 2013, respectively.

\subsubsection{Correlation coefficients between pollen concentrations and meteorological parameters}

The correlation coefficients between Corylus pollen and meteorological parameters as measured on the same day are statistically significant for all parameters except for those from $T_{\max }$ and $T$ in the year 2013 at the Park station. In the same year for the City station, the correlation was non-significant for $T_{\max }$ and $T, V$ and $\mathrm{SR}_{\mathrm{d}}$. The highest negative significant correlation was calculated for RH $(-0.71)$ at the Park station. In 2014, the correlation between pollen concentrations and relative humidity was lower than that in 2013. At the Park station, the highest significant correlation was observed for $T_{\max }(0.58)$ and $\mathrm{RH}(-0.52)$. At the City station, a positive correlation was calculated between pollen concentrations and $T_{\min }, \mathrm{RH}_{\max }$ and $\mathrm{SD}$, and these correlations were statistically significant (Table 2).

The Spearman's correlation coefficient for pollen concentrations and several meteorological parameters from the previous day are significant for the year 2013 . In that year, the highest negative coefficient for the Park station was for RH $(-0.56)$. For the City station, it was for $T_{\min }(-0.57)$. In 2013, a high positive correlation reached $\mathrm{SD}(0.45)$ and $\mathrm{SR}_{\mathrm{t}}(0.43)$ at the Park station. In 2014, the number of significant correlated parameters was lower than that in 2013. At the Park station in 2014, a significant correlation was shown for $T(0.34)$ and $T_{\max }(0.45), \mathrm{RH}(-0.29)$ and $\mathrm{SR}_{\mathrm{t}}(0.3)$ and $\mathrm{SR}_{\mathrm{d}}(0.33)$. At the City station, only $\mathrm{RH}_{\max }$ was significantly correlated with Corylus concentrations (0.44) (Table 3).

\subsubsection{Back-trajectories analysis with the HYSPLIT model}

In 2013, the differences between the directions of air masses' inflow were seen at different heights. At height $50 \mathrm{~m}$, the inflow was mainly from the northwest, north-east, and south-east for both City and Park stations. With the increase in the altitude of trajectories at $1500 \mathrm{~m}$, the inflow was dominant from the western direction for both City and Park stations, and with little contribution from the northern, eastern, southern, and south-western directions (Fig. 3). At all altitudes, trajectories crossed the area at which Corylus shrubs are observed. The correlation coefficient between the maps of trajectories' frequency for the City and the Park stations did not exceed 0.48 ( $p$ value $<2.2 \mathrm{e}-16$ ) and decreased with increasing height of trajectories.

During the whole 2014 Corylus pollen season, the inflow of air masses was mainly from the southwestern, southern, and south-eastern directions. For the Park station, the frequency of the inflow from south-eastern direction was more noticeable than for the City station. At a height of $1500 \mathrm{~m} \mathrm{agl}$, the contribution of western and south-western directions was dominant. For the City station, the inflow was more dispersed than for the Park station (Fig. 4). The correlation coefficient between the maps of trajectories' frequency for the City and the Park stations did not exceed 0.44 ( $p$ value $<2.2 \mathrm{e}-16$ ) and decreased with increasing height of trajectories.

\subsection{Alnus}

\subsubsection{Pollen season}

In the case of Alnus, differences at the start and end of the season between the sampling sites were smaller- 


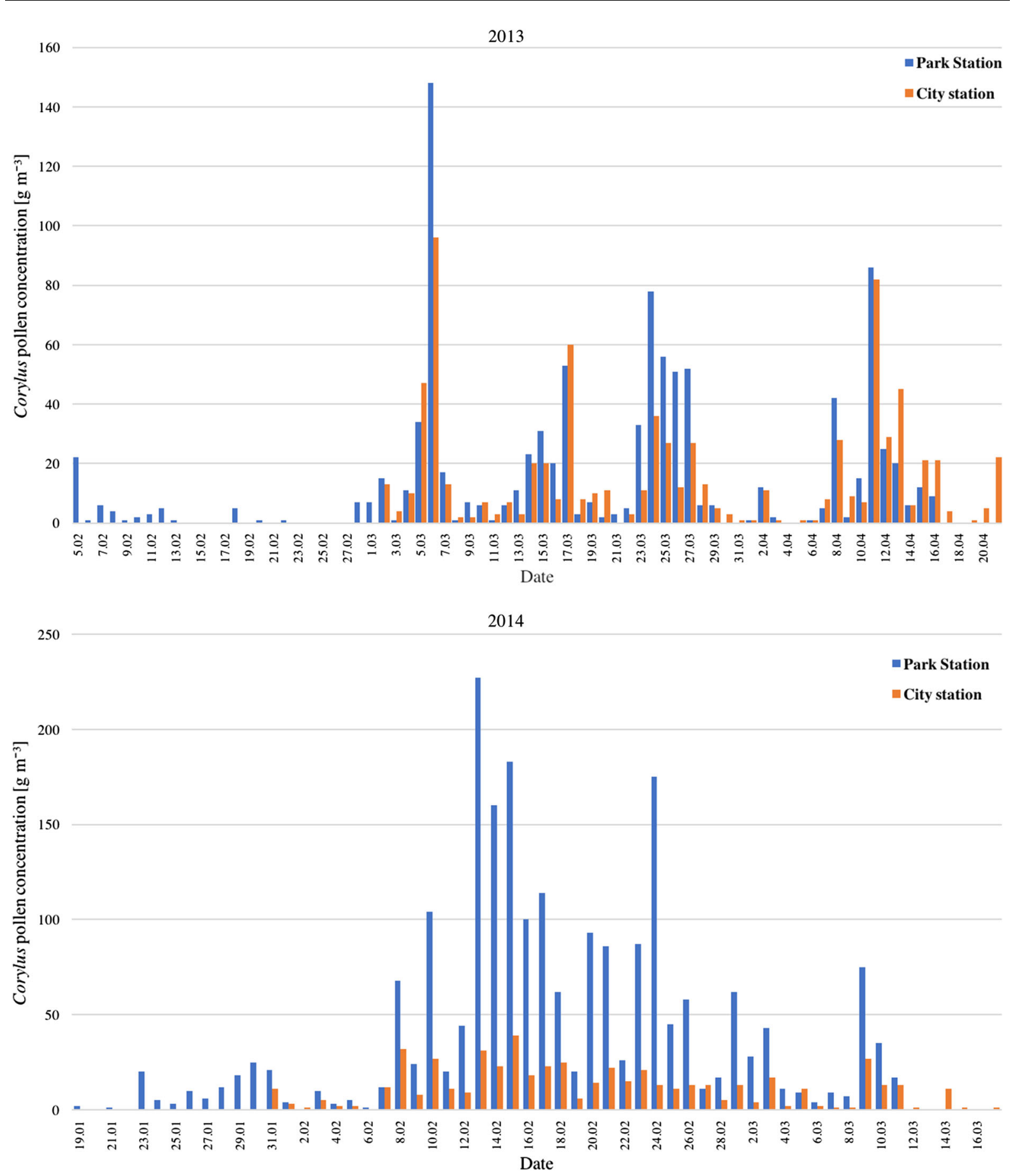

Fig. 2 Distribution of Corylus pollen in 2013 and 2014 for the Park station and the City station 
Table 2 Spearman's correlation coefficient for Corylus pollen and meteorological data from the same day

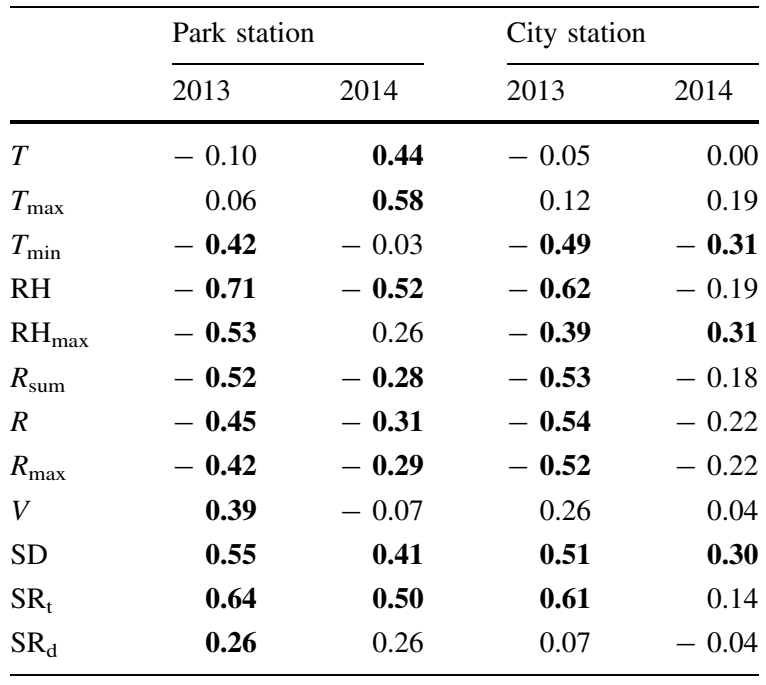

Bold-statistically significant $(p$ value $<0.05)$

Table 3 Spearman's correlation coefficient for Corylus pollen and meteorological data from the previous day

\begin{tabular}{|c|c|c|c|c|}
\hline & \multicolumn{2}{|c|}{ Park station } & \multicolumn{2}{|c|}{ City station } \\
\hline & 2013 & 2014 & 2013 & 2014 \\
\hline$T_{\max }$ & -0.01 & 0.45 & -0.23 & 0.03 \\
\hline$T_{\min }$ & -0.38 & 0.00 & -0.57 & -0.16 \\
\hline$T$ & -0.14 & 0.34 & -0.31 & -0.10 \\
\hline $\mathrm{RH}$ & -0.56 & -0.29 & -0.39 & 0.16 \\
\hline $\mathrm{RH}_{\max }$ & -0.39 & 0.22 & -0.26 & 0.44 \\
\hline$R_{\text {sum }}$ & -0.41 & 0.17 & -0.46 & -0.02 \\
\hline$R_{\max }$ & -0.31 & 0.14 & -0.36 & 0.05 \\
\hline$R$ & -0.32 & -0.15 & $-\mathbf{0 . 3 7}$ & 0.04 \\
\hline$V$ & 0.28 & -0.20 & 0.05 & 0.00 \\
\hline SD & 0.45 & 0.21 & 0.33 & 0.09 \\
\hline $\mathrm{SR}_{\mathrm{t}}$ & 0.43 & 0.30 & 0.31 & -0.05 \\
\hline $\mathrm{SR}_{\mathrm{d}}$ & -0.13 & 0.33 & -0.13 & 0.13 \\
\hline
\end{tabular}

Bold-statistically significant

the maximum shift did not exceed 1 day, and the season started earlier at the City station. The SPIn was highest in 2014 at the Park station (9846 pollen grains $\mathrm{m}^{-3}$ ) and lowest in 2013 also at the Park station (2541 pollen grains $\mathrm{m}^{-3}$ ). The duration of the pollen season varied from 29 days in 2014 at the Park station to 48 days in 2013 at the City station. The highest daily pollen concentration was measured in 2014 at the Park station (1853 pollen grains $\mathrm{m}^{-3}, 9$ March) (Table 4).

The temporal distribution of Alnus pollen during the analysed 2 years was similar at both stations (Park and City). There was only one main peak observed for each year. The amount of pollen was similar at both Park and the City stations (Fig. 5). The correlation coefficient of pollen concentration between sites reached 0.94 ( $p$ value $<0.01$ ) in 2013 and 0.91 in 2014 ( $p$ value $<0.01)$.

\subsubsection{Correlation coefficients between pollen concentrations and meteorological parameters}

With regard to Alnus pollen, for meteorological data from the same day as pollen data, the highest negative Spearman's correlation coefficient was for RH $(-0.65)$ at the Park station in 2013. For the same station and in the same year, the highest positive correlation was 0.60 for the total $\mathrm{SR}_{\mathrm{t}}$. For the Park station in 2014, the significant correlation was for $T_{\min }, T_{\max }, \mathrm{RH}_{\max }, \mathrm{SD}, \mathrm{SR}_{\mathrm{t}}$, and $\mathrm{SR}_{\mathrm{d}}$. For the City station in the same year, $T_{\max }, \mathrm{RH}_{\max }$, and $\mathrm{SD}$ were correlated positively with Alnus pollen concentrations. A negative correlation was observed for $R_{\text {sum }}$ (Table 5).

The Spearman's correlation coefficient for Alnus pollen and meteorological data from the previous day in the case of the Park station for 2013 was significant for $\mathrm{RH}_{\max }(-0.45), \mathrm{RH}(-0.57), R_{\text {sum }}(-0.53)$, $R_{\max }(-0.33), R(-0.37)$, SD (0.39), and $\mathrm{SR}_{\mathrm{t}}(0.47)$. At the City station, the correlation was lower, reaching -0.44 for $\mathrm{RH}$ and $\mathrm{RH}_{\max },-0.46$ for $R_{\text {sum }}, 0.30$ for $\mathrm{SD}$, and 0.38 for $\mathrm{SR}_{\mathrm{t}}$. In 2014 at the Park station, a significant correlation was observed for $T_{\max }(0.39)$ and $\mathrm{SR}_{\mathrm{t}}(0.4)$. For the City station, a positive correlation was observed for SD (0.38) (Table 6).

\subsubsection{Back-trajectories analysis with the HYSPLIT model}

During the whole Alnus pollen season in 2013, the direction of the inflow of air masses differed at different heights. At $50 \mathrm{~m}$, it was mainly from northeastern, south-eastern, and north-western directions 

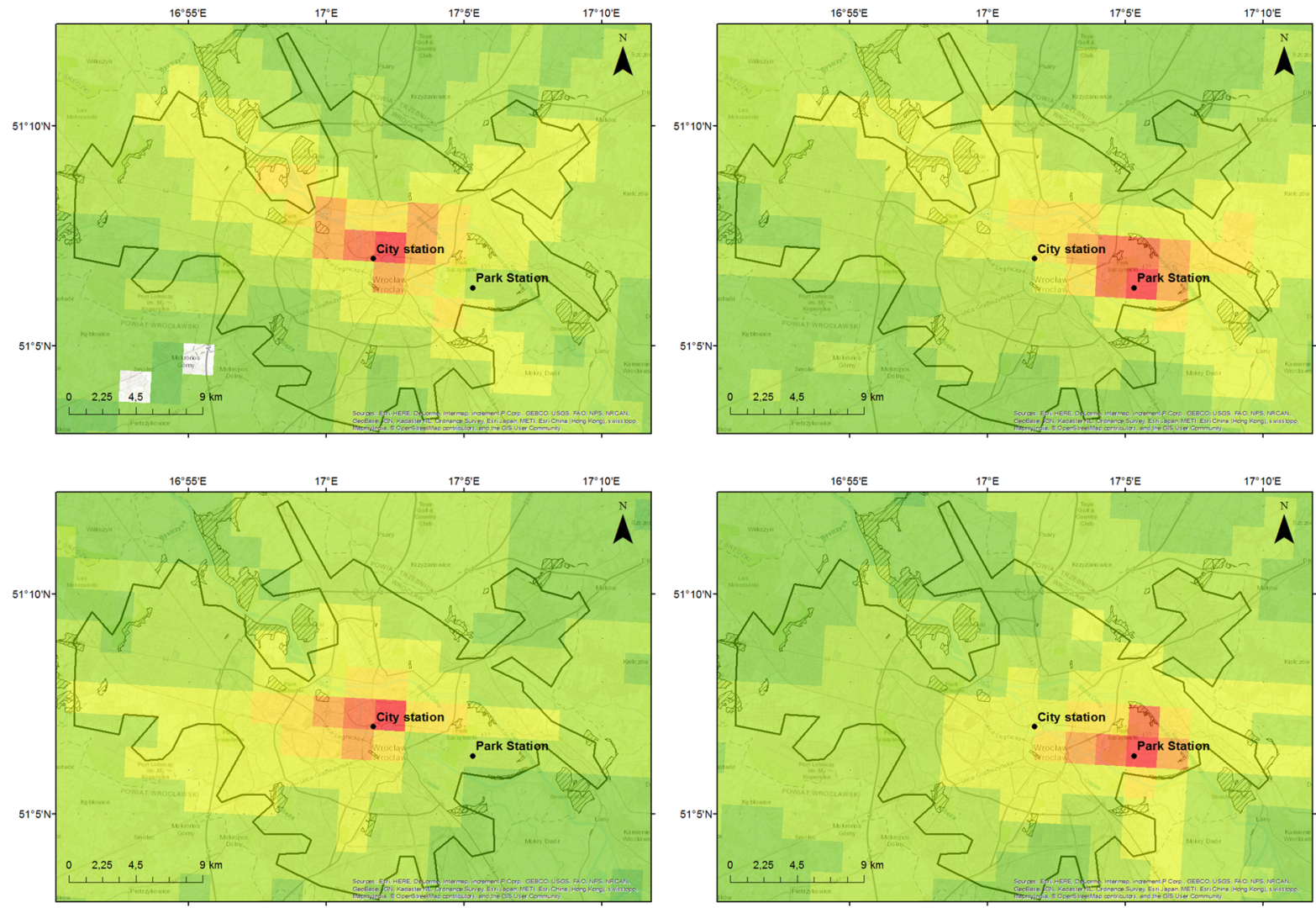

The number of trajectories frequency in each grid cell.

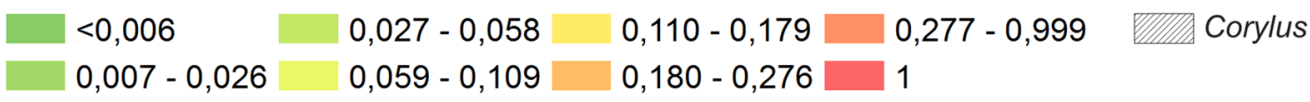

Fig. 3 Trajectories' frequency in each grid cell for the Corylus season in 2013 for the City station (left side) and the Park station (right side), for $50 \mathrm{~m}$ and $1500 \mathrm{~m}$ agl. (From top to bottom row)

for both City and Park stations. At $1500 \mathrm{~m}$, the inflow of air masses was mainly from the western direction, but with contribution from northern, eastern, and south-eastern directions (Fig. 6). At both altitudes, the trajectories crossed the areas with the presence of Alnus trees. The correlation coefficient between the maps of trajectories' frequency for both City and Park stations did not exceed 0.43 ( $p$ value $<2.2 \mathrm{e}-16$ ) and decreased with increasing height of trajectories.

For the "high" group (i.e. days with Alnus pollen concentration above 85 pollen grains $\mathrm{m}^{-3}$ ), for the City station, the inflow of air masses at $50 \mathrm{~m}$ was from the southern and south-eastern directions, but with little contribution of air masses from the north-western direction. For the Park station, the advection was seen from the south-western direction, but with little contribution from the western direction. At $1500 \mathrm{~m}$, the direction of air masses inflow in case of the City station was also more scattered than at the Park station. The main directions of air masses inflow were from the western and south-western directions, with contribution from the northern and north-western directions. In the case of the Park station, the inflow was mainly from south-western and western directions but with contribution from the south and north-west (Fig. 7). The areas with the presence of Alnus trees were crossed at both trajectories' height. The correlation coefficient between the maps of trajectories' 

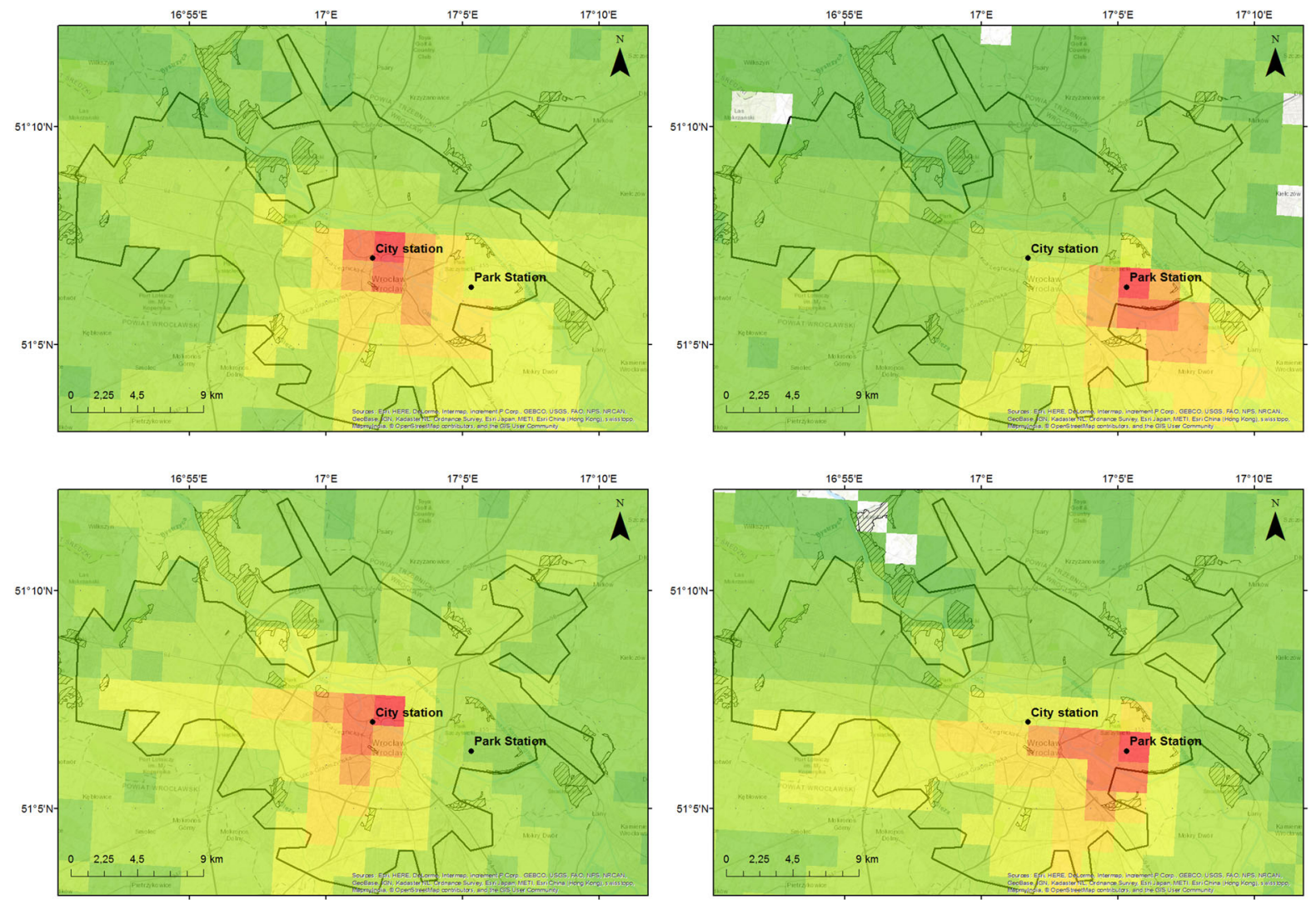

The number of trajectories frequency in each grid cell.

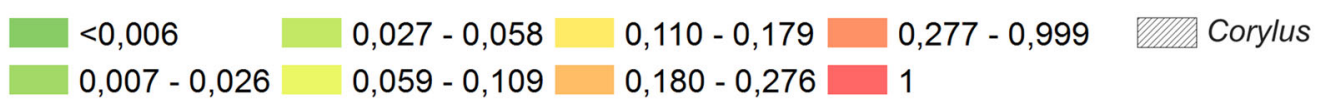

Fig. 4 Trajectories' frequency in each grid cell for the Corylus season in 2014 for the City station (left side) and the Park station (right side), for $50 \mathrm{~m}$ and $1500 \mathrm{~m}$ agl. (From top to bottom row)

Table 4 Characteristic of Alnus pollen season

\begin{tabular}{|c|c|c|c|c|}
\hline & \multicolumn{2}{|c|}{ Park station } & \multicolumn{2}{|c|}{ City station } \\
\hline & 2013 & 2014 & 2013 & 2014 \\
\hline Seasonal Pollen Integral (SPIn) & 2541 & 9846 & 4638 & 4575 \\
\hline The start of pollen season & 06.03 & 11.02 & 05.03 & 10.02 \\
\hline The end of pollen season & 21.04 & 11.03 & 21.04 & 14.03 \\
\hline Duration of pollen season (days) & 47 & 29 & 48 & 33 \\
\hline \multirow[t]{2}{*}{ Maximum pollen concentration (grains $/ \mathrm{m}^{3}$ air)/date } & 800 & 1853 & 881 & 785 \\
\hline & 11.04 & 09.03 & 11.04 & 09.03 \\
\hline
\end{tabular}

frequency for the City and Park stations changed with altitude; at $50 \mathrm{~m}$, it reached 0.23 , and at $1500 \mathrm{~m}$, it was 0.24 ( $p$ value $<2.2 \mathrm{e}-16$ )

For "peak" group in 2013, the inflow of air masses at $50 \mathrm{~m}$ for both stations was mainly from the south.
At $1500 \mathrm{~m}$, there was a noticeably larger participation from the south-western direction in the case of both stations (Fig. 8). During "peak" group, the air masses flowed over the areas with the presence of the Alnus trees. The correlation coefficient between the maps of 


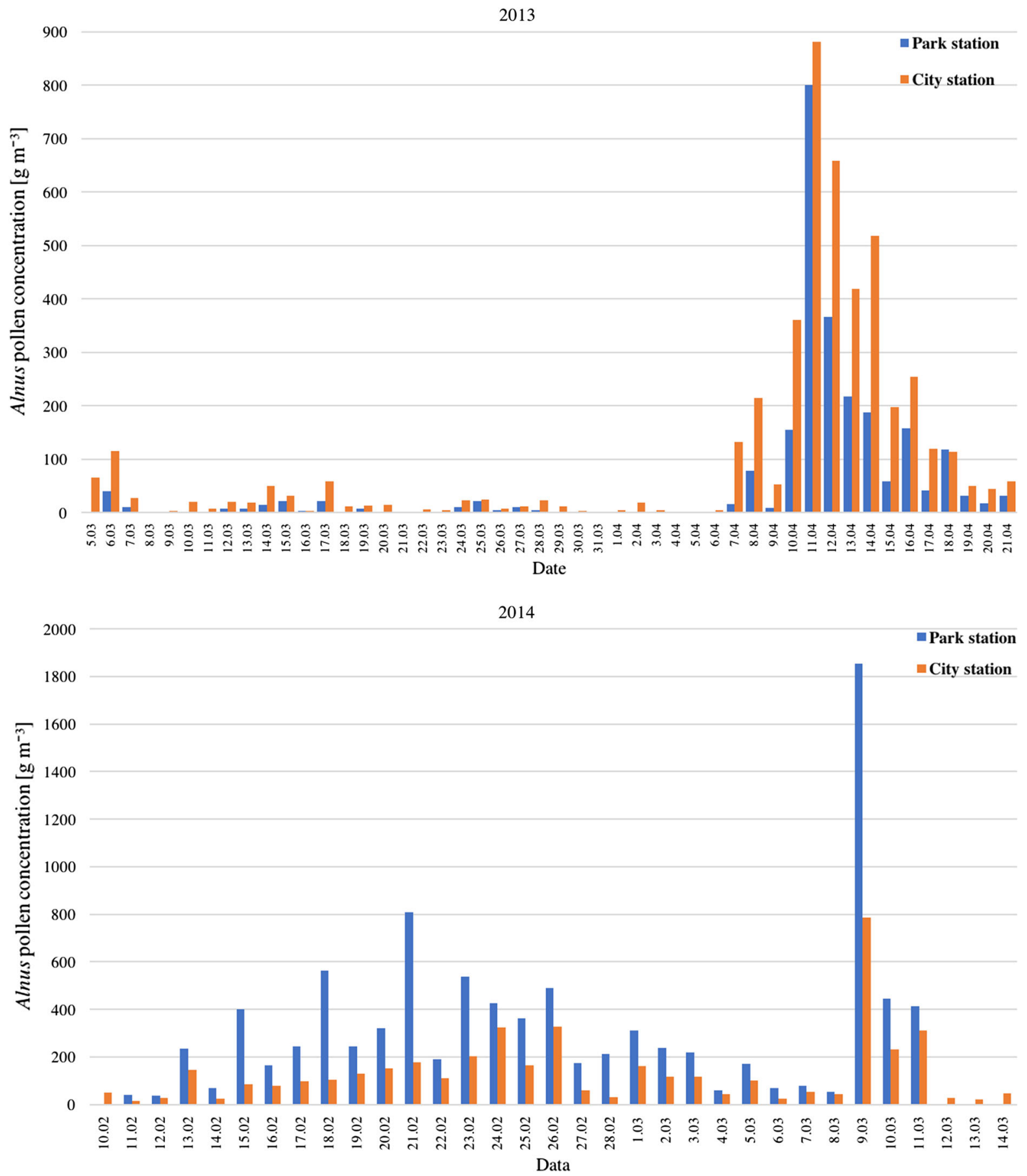

Fig. 5 Distribution of Alnus pollen in 2013 and 2014 for the Park station and the City station

trajectories' frequency for both City and Park stations was very low and did not exceed 0.04 ( $p$ value $<2.2 \mathrm{e}-16)$ and decreased with increasing height of trajectories.
During the whole Alnus pollen season in 2014, the inflow of air masses was mainly from the south and south-east. At $1500 \mathrm{~m}$, the main inflow of air masses was from the west (Fig. 9). At both altitudes, the air 
Table 5 Spearman's correlation coefficient for Alnus pollen and meteorological data from the same day

\begin{tabular}{|c|c|c|c|c|}
\hline & \multicolumn{2}{|c|}{ Park station } & \multicolumn{2}{|c|}{ City station } \\
\hline & 2013 & 2014 & 2013 & 2014 \\
\hline$T$ & 0.09 & 0.06 & 0.33 & 0.00 \\
\hline$T_{\max }$ & 0.22 & 0.74 & 0.44 & 0.41 \\
\hline$T_{\min }$ & -0.25 & -0.45 & -0.07 & -0.25 \\
\hline RH & -0.65 & -0.17 & -0.54 & 0.05 \\
\hline $\mathrm{RH}_{\max }$ & -0.38 & 0.38 & -0.25 & 0.35 \\
\hline$R_{\text {sum }}$ & -0.56 & -0.21 & -0.55 & -0.29 \\
\hline$R$ & -0.40 & -0.21 & -0.39 & -0.34 \\
\hline$R_{\max }$ & -0.38 & -0.20 & -0.37 & -0.33 \\
\hline$V$ & 0.00 & -0.03 & -0.06 & 0.01 \\
\hline SD & 0.45 & 0.41 & 0.48 & 0.34 \\
\hline $\mathrm{SR}_{\mathrm{t}}$ & 0.60 & 0.58 & 0.61 & 0.33 \\
\hline $\mathrm{SR}_{\mathrm{d}}$ & 0.45 & -0.43 & 0.33 & -0.12 \\
\hline
\end{tabular}

Bold-statistically significant

Table 6 Spearman's correlation coefficient for Alnus pollen and meteorological data from the previous day

\begin{tabular}{|c|c|c|c|c|}
\hline & \multicolumn{2}{|c|}{ Park station } & \multicolumn{2}{|c|}{ City station } \\
\hline & 2013 & 2014 & 2013 & 2014 \\
\hline$T$ & 0.08 & -0.12 & 0.17 & -0.22 \\
\hline$T_{\max }$ & 0.16 & 0.39 & 0.21 & 0.22 \\
\hline$T_{\min }$ & -0.14 & -0.12 & -0.04 & -0.18 \\
\hline $\mathrm{RH}$ & -0.57 & 0.01 & -0.44 & 0.27 \\
\hline $\mathrm{RH}_{\max }$ & -0.45 & 0.17 & -0.44 & 0.32 \\
\hline$R_{\text {sum }}$ & -0.53 & -0.25 & -0.46 & -0.24 \\
\hline$R$ & -0.37 & -0.14 & -0.30 & -0.17 \\
\hline$R_{\max }$ & -0.33 & -0.14 & -0.27 & -0.17 \\
\hline$V$ & -0.10 & -0.16 & -0.17 & -0.11 \\
\hline SD & 0.39 & 0.33 & 0.30 & 0.38 \\
\hline $\mathrm{SR}_{\mathrm{t}}$ & 0.47 & 0.40 & 0.38 & 0.19 \\
\hline $\mathrm{SR}_{\mathrm{d}}$ & 0.14 & -0.08 & -0.01 & 0.07 \\
\hline
\end{tabular}

Bold-statistically significant

masses inflow was over areas covered with Alnus trees. The correlation coefficient between the maps of trajectories' frequency for both City and Park stations did not exceed 0.38 ( $p$ value $<2.2 \mathrm{e}-16$ ) and decreased with increasing height of trajectories.
During the "high" group in 2014 (days with Alnus pollen concentration above 85 pollen grains $\mathrm{m}^{-3}$ ), at $50 \mathrm{~m}$ the inflow of air masses was mainly from the south-eastern direction, but the southern direction was also marked. At $1500 \mathrm{~m}$, the significance of air masses from the south-east was lower, while the highest contribution of air masses was from the western direction (Fig. 10). At both altitudes, trajectories crossed the area at which Alnus trees are observed. The correlation coefficient between the maps of trajectories' frequency for both City and Park stations differed according to different altitudes of trajectories and reached 0.44 for $50 \mathrm{~m}$ and 0.34 for $1500 \mathrm{~m}$ ( $p$ value $2.2 \mathrm{e}-16$ ).

Major differences between the stations and arriving air masses were found for the "peak" group in 2014 (days for which the measured pollen concentrations increased rapidly in comparison with the previous day). At $50 \mathrm{~m}$, the main direction of inflow was from the south and south-east for the City station and south with little contribution from the south-east for the Park station. At $1500 \mathrm{~m}$, for the City station, the inflow of air masses was scattered from the north-eastern, eastern, south-eastern, southern, and south-western directions. For the Park station, air masses came mainly from the south-western direction (Fig. 11). At both altitudes, trajectories crossed the area at which Alnus trees are present. The correlation coefficient between the raster of trajectories' frequency was small and did not exceed 0.17 ( $p$ value $<2.2 \mathrm{e}-16$ ) and decreased with increasing height of trajectories.

\section{Discussion}

According to Kasprzyk (2010), the start of pollination can vary even on a local scale, depending on the type of habitat. Her analysis has shown that even a small increase in temperature or more sunlight favours pollination and an earlier start to the season of Corylus (Kasprzyk 2010). Pollen grain concentration is sensitive to temperature, which was confirmed by Dąbrowska-Zapart et al. (2018) for Alnus and by Gottardini and Cristofolini (1997) for Corylus. In our study, we observed the negative significant correlation between Corylus pollen concentrations and daily minimum temperature. High pressure, low cloudiness, and calm wind speed during the night are favourable for low minimum temperatures. On contrary, the same 

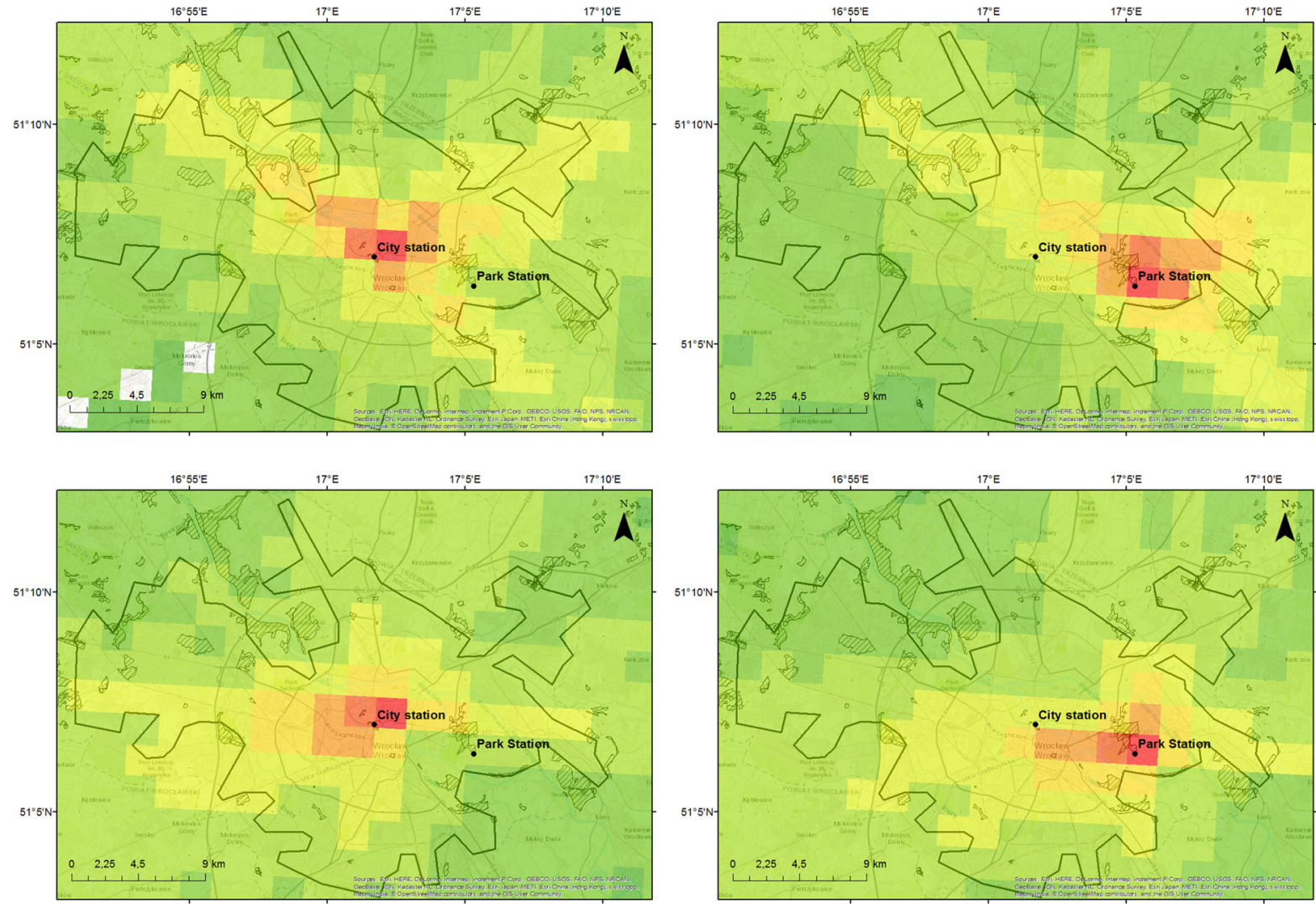

The number of trajectories frequency in each grid cell.

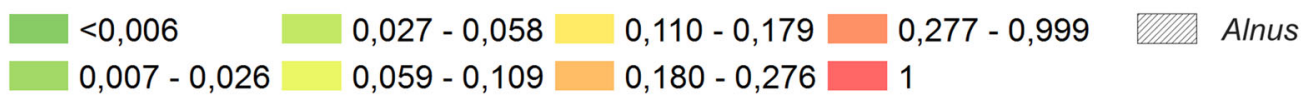

Fig. 6 Trajectories' frequency in each grid cell for the Alnus season in 2013 for the City station (left side) and the Park station (right side) for $50 \mathrm{~m}$ and $1500 \mathrm{~m}$ agl. (From top to bottom row)

weather patterns are favourable to increased solar radiation and relatively high temperatures during the day (Szewczak 2014). During days with high solar radiation (and increased daytime temperatures), some Corylus shrubs could release their pollen earlier. For the same day were observed relatively low minimum air temperatures. Puc and Kasprzyk (2013) also claimed that differences in the time and fluctuation of the pollen season are caused by local weather conditions. Piotrowska-Weryszko (2013) showed that local meteorological factors influence the pollen peak shift (in 2002, it reached over a month) between stations located in different regions of Poland. Our study has also shown that the meteorological conditions have an impact on the variability of pollen season. This is proven by the statistically significant correlation between meteorological factors and pollen concentration from the same day.

As was shown in other studies, meteorology from a longer period (e.g. sum of the temperatures several weeks before the start of the pollen season) is important to start flowering. Especially at the start of the season, air temperature preceding Alnus or Corylus pollination is very important, because it influences on the pollen emission (Rodriguez-Rajo et al. 2004; Dąbrowska-Zapart 2008; Piotrowska and Kaszewski 

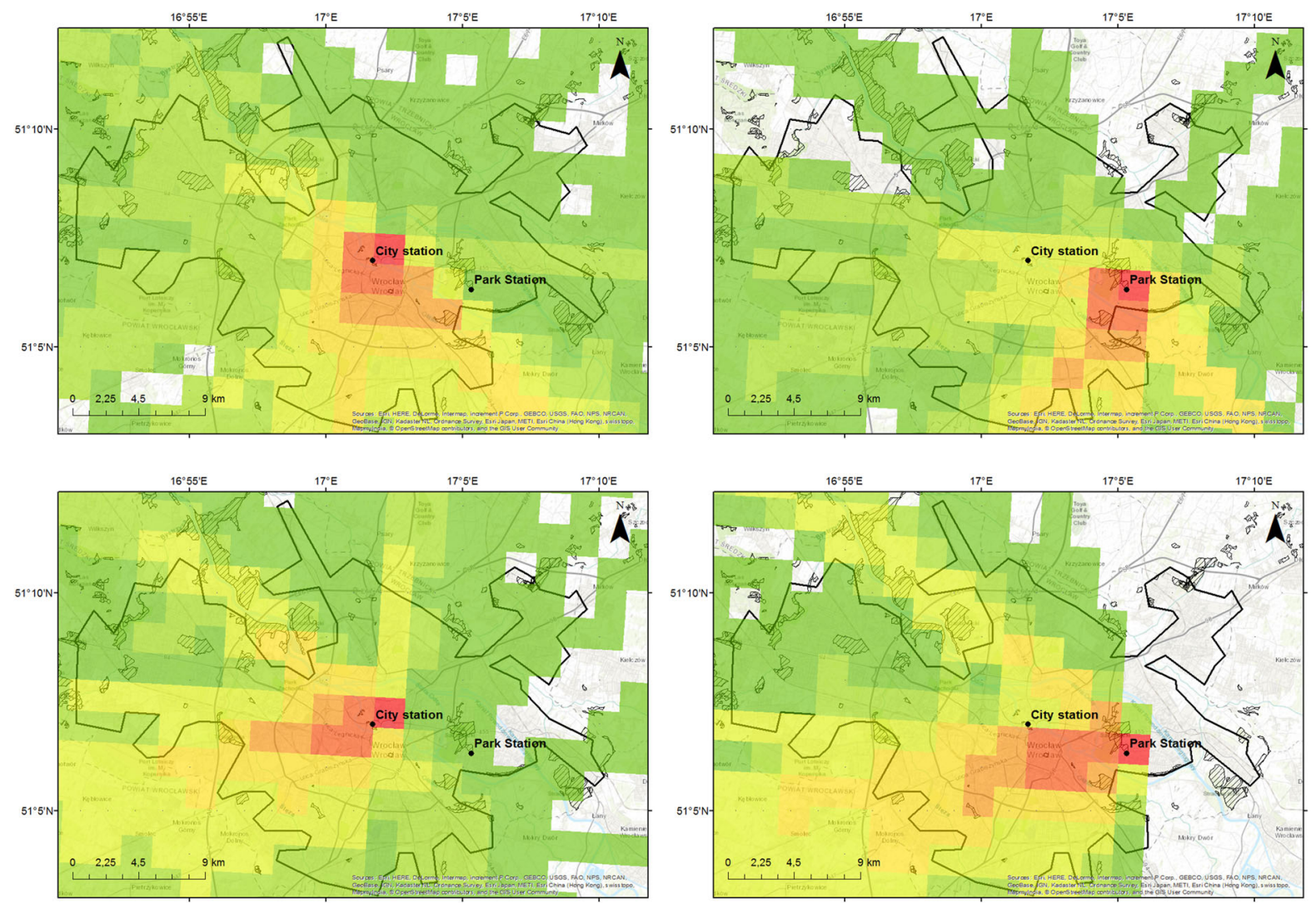

The number of trajectories frequency in each grid cell.

\begin{tabular}{|c|c|c|c|}
\hline$<0,006$ & $0,027-0,058$ & $0,110-0,179$ & $0,277-0,999$ \\
\hline $0,007-0,026$ & $0,059-0,109$ & $0,180-0,276$ & 1 \\
\hline
\end{tabular}

Fig. 7 Trajectories' frequency in each grid cell for the Alnus "high" group in 2013 for the City station (left side) and the Park station (right side) for $50 \mathrm{~m}$ and $1500 \mathrm{~m}$ agl. (From top to bottom row)

2009; Myszkowska et al. 2010; Malkiewicz et al. 2016). In our study, we have shown that meteorological parameters from the same day as pollen concentration have a greater influence on pollen concentration than meteorological parameters from the previous day. Similar dependences showed also Kasprzyk (2013) - in her findings, the correlation coefficient between Corylus and Alnus pollen grains and current meteorology conditions was higher than for meteorology condition from the previous day.

Analysis of trajectories is widely used in order to identify the most probable location of air pollution sources (Cesari et al. 2014; Godłowska et al. 2015) as well as any pollen source location or movement (Smith et al. 2005; Stach et al. 2007; Bilińska et al.
2017). The back-trajectories were used in a study conducted by Skjøth et al. (2015) which investigated the source of Betula pollen in Wrocław and Worcester. Their study showed that the pollen concentration in the air is mainly provided by local trees (Skjøth et al. 2015). According to Myszkowska et al. (2010), Alnus is sensitive to wind speed, which promotes the release and distribution of its pollen. In the case of Corylus, Stępalska et al. (2016) showed that its pollen remains in the air longer than flowering season lasting, and thus, a long-range transport and analysis of trajectories may play an important role in understanding Corylus pollen air concentrations.

In our study, back-trajectories have shown that the inflow of air masses was the most diverse between the 

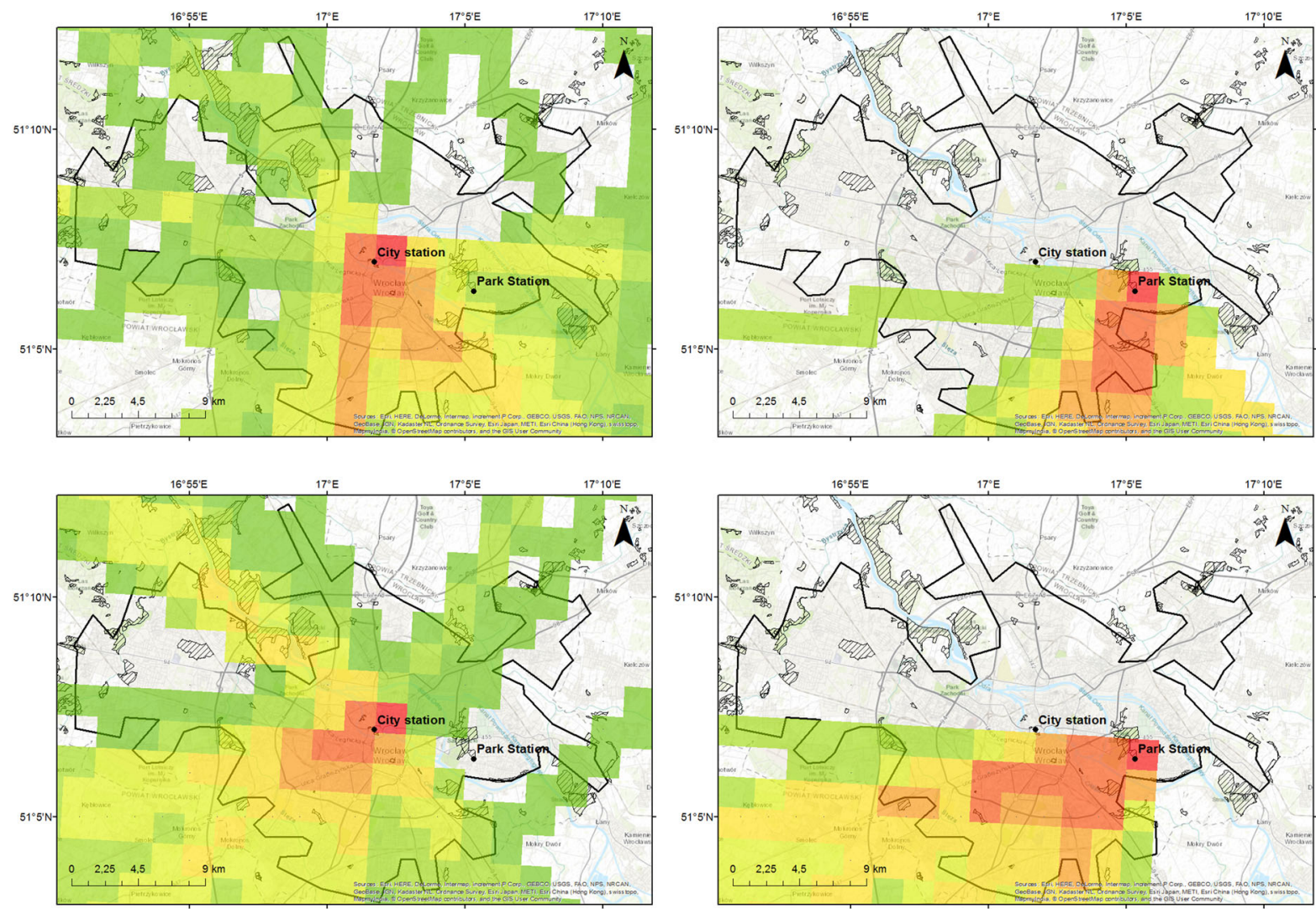

The number of trajectories frequency in each grid cell.

\begin{tabular}{|c|c|c|}
\hline 06 & $7-0,058$ & $0,110-0,179 \quad 0,277-0,999$ \\
\hline 026 & & $0,180-0,276$ \\
\hline
\end{tabular}

Fig. 8 Trajectories' frequency in each grid cell for the Alnus "peak" group in 2013 for the City station (left side) and the Park station (right side) for $50 \mathrm{~m}$ and $1500 \mathrm{~m}$ agl. (From top to bottom row)

stations for the Alnus high-concentration episodes, especially in 2014. In other cases (trajectories for the whole season of Corylus and Alnus both in 2013 and 2014 and high Alnus episodes in 2013), the transport of air masses was also strongly different for both stations. It suggests that in explaining the variability of the pollen season between two stations located close to each other, both the meteorological conditions and surrounding of the sampling sites are important, which was also noted by Charalampopoulos et al. (2018). According to Rojo et al. (2015), green areas in close proximity to pollen traps strongly influence the number of pollen in the air. Borycka and Kasprzyk (2018) found that the Alnus SPIn and daily concentration in Rzeszów (Poland) were higher in the suburbs, where more alder trees grow, than in downtown. In our study, the start of the pollen season in the case of Corylus was observed earlier at the Park station than at the City station in each of the analysed year. This shift between the start of the pollen season reached even 25 days in 2013. The earlier appearance of Corylus pollen at the Park station can be caused by the fact that in close proximity to the Park station there are a few Corylus shrubs and a bit further there is a big park with higher number of hazel. There is no hazel shrub in the vicinity of the City station. In the case of Alnus, these differences were not as pronounced as in the case of Corylus, in terms of both start/end of the pollen season and observed maximum concentrations of pollen. This might be explained by the fact that 

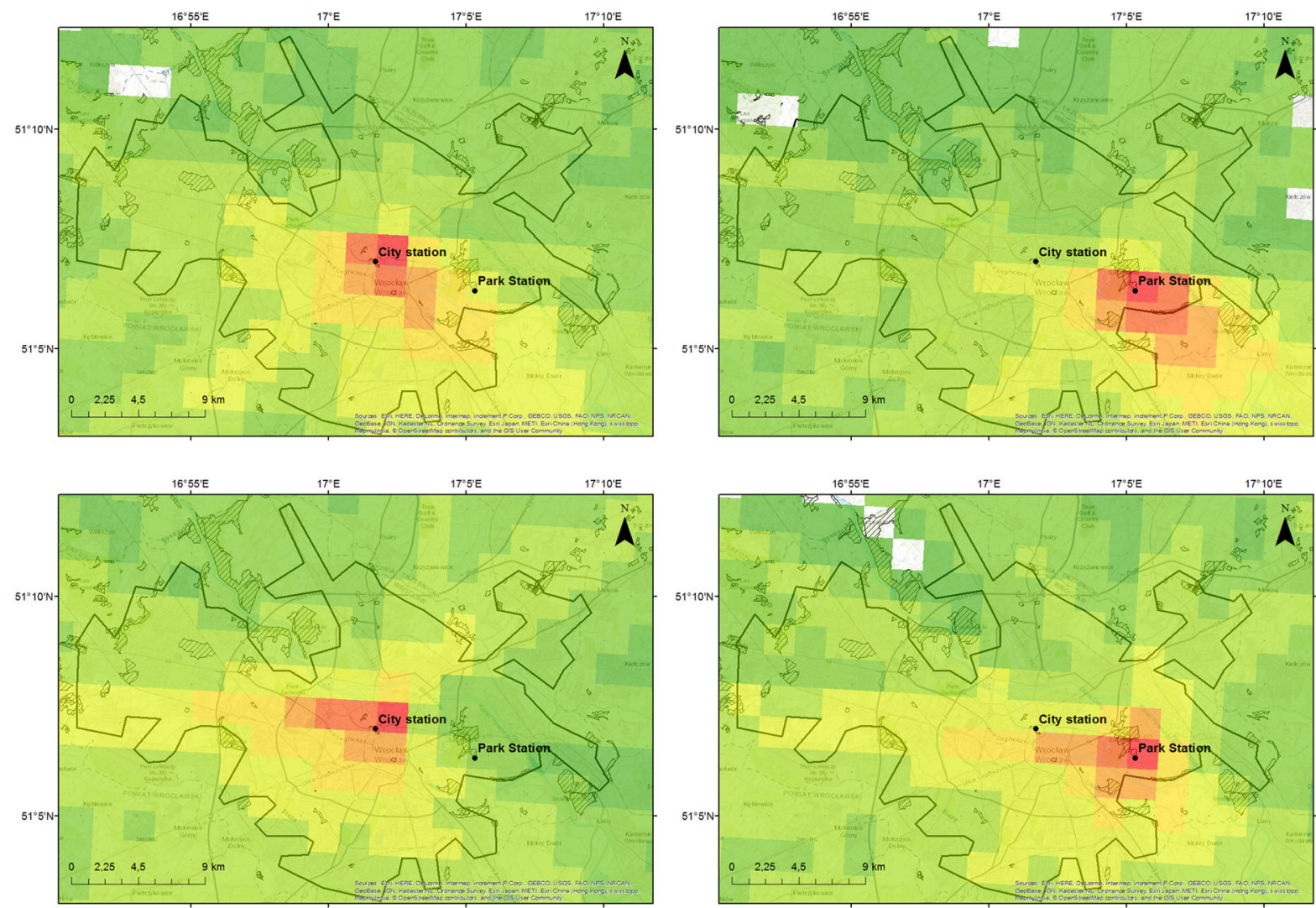

The number of trajectories frequency in each grid cell.

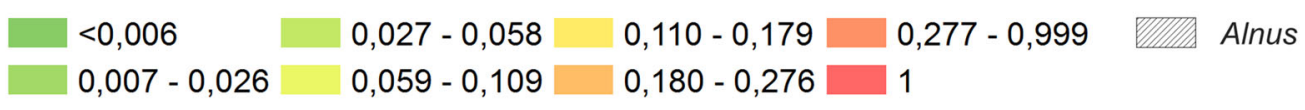

Fig. 9 Trajectories' frequency in each grid cell for the Alnus season in 2014 for the City station (left side) and the Park station (right side) for $50 \mathrm{~m}$ and $1500 \mathrm{~m}$ agl. (From top to bottom row)

Alnus trees grow in a short distance from both stations. The next evidence of the significance of the vicinity of station on the pollen concentration is the SPIn of Alnus at Park station in 2013 and 2014. In 2013, the Alnus SPIn was almost twice lower than in 2014. This could be linked to the land-use changes that were related to the development of the river system in Wrocław. In 2012-2013, embankment of Odra River near the Park station was rebuilt, whereas the areas close to the rivers in Wrocław are the main areas where the Alnus trees grow. During this redevelopment, some trees were removed and this could be the reason why lower
SPIn was observed in 2013. However, we are not able to support this information quantitatively.

Also, analysis of trajectories on different heights suggests that the main source of pollen is local trees rather than distant transport. At 1500 meters, the dominant flow showed by trajectories was from western directions which is consistent with the general climatological circulation for Poland (Woś 1999). More important are trajectories calculated at height of $50 \mathrm{~m}$ above ground level. Their direction can show the possible sources of pollen. In our study, maps with trajectories' frequency at $50 \mathrm{~m}$ above ground level 

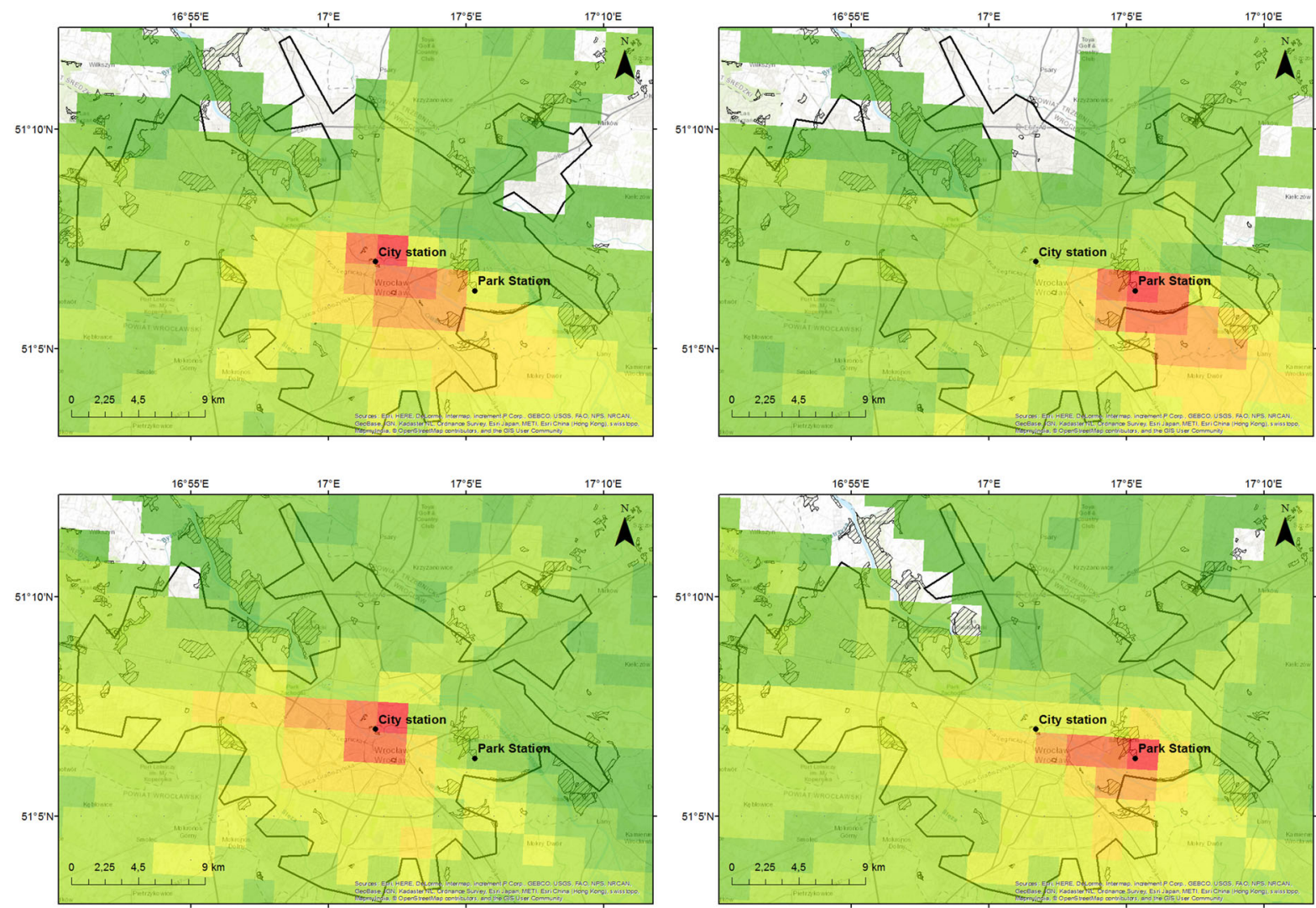

The number of trajectories frequency in each grid cell.

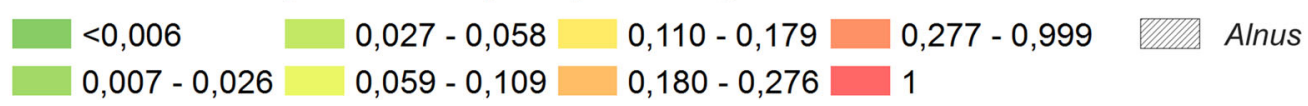

Fig. 10 Trajectories' frequency in each grid cell for the Alnus "high" group in 2014 for the City station (left side) and the Park station (right side) for $50 \mathrm{~m}$ and $1500 \mathrm{~m}$ agl. (From top to bottom row)

show that in the case of "high" or "peak" groups, air masses flow above the area with Alnus trees and Corylus shrubs.

Our analyses of trajectories have shown that there are the differences in the inflow of air masses even for two stations located close to each other. The correlation coefficient between the maps of trajectories' frequency did not exceed 0.44 and decreased with increasing height of trajectories, which also confirmed the differences in inflow between the two stations. It is particularly visible in the case of Alnus episode, where at higher altitudes the direction of inflow of air masses inflow is significantly different, which is also confirmed by the low or insignificant correlation coefficient.

\section{Conclusion}

Our study has shown that it is possible that the pollen concentration varies greatly even in sampling sites located close to each other (c.a. $4 \mathrm{~km}$ ). This variability can differ according to years. The most important parameter that causes differences between stations is the presence of Alnus trees or Corylus shrubs in close proximity. Meteorological factors contribute to the 

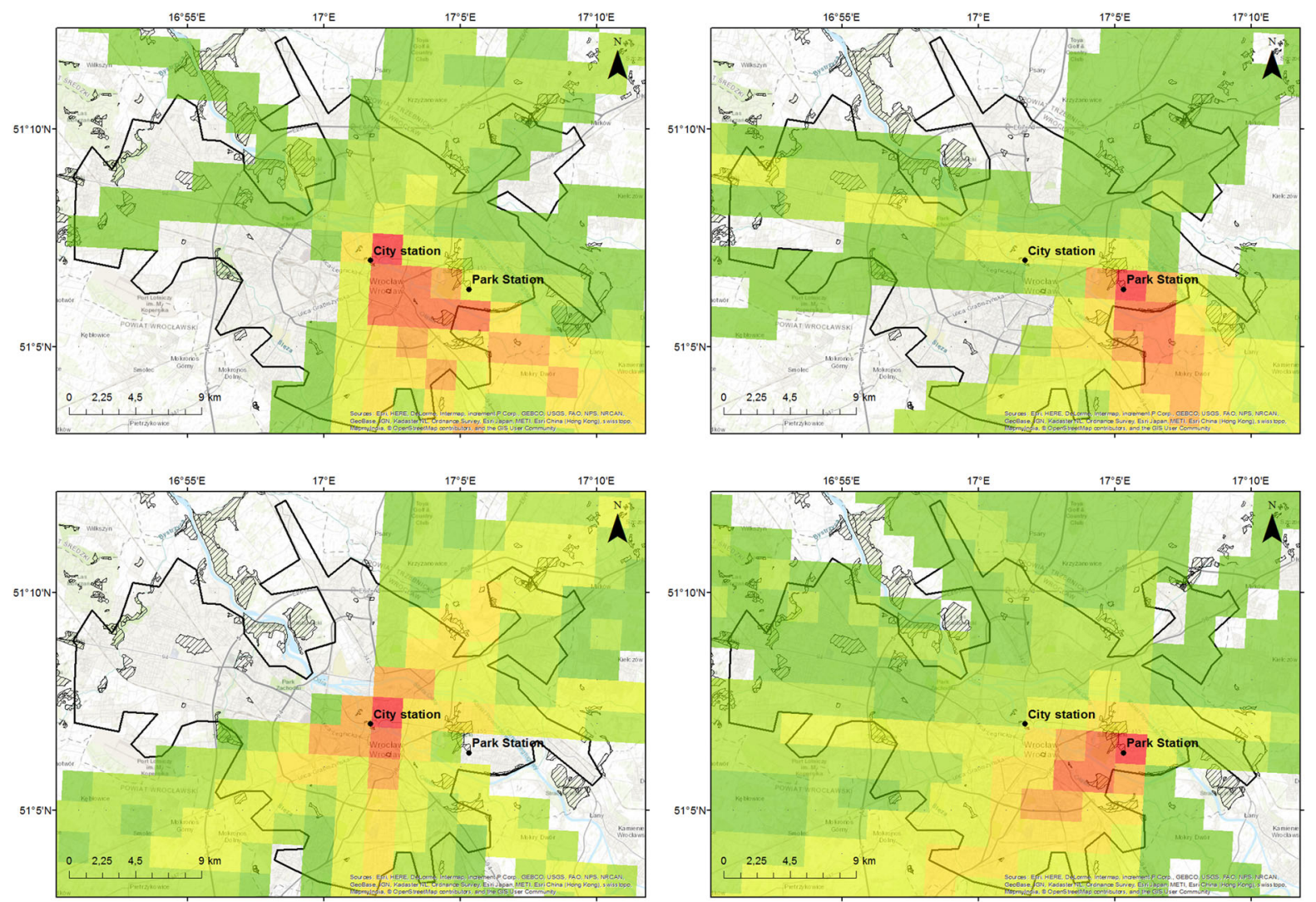

The number of trajectories frequency in each grid cell.

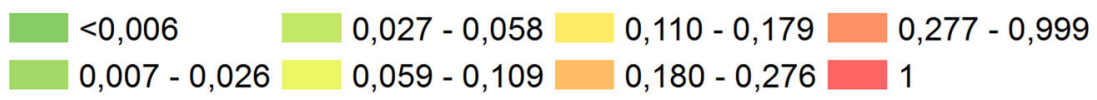

\section{Landcover}

Alnus

Fig. 11 Trajectories' frequency in each grid cell for the Alnus "peak" group in 2014 for the City station (left side) and the Park station (right side) for $50 \mathrm{~m}$ and $1500 \mathrm{~m}$ agl. (From top to bottom row)

variability of the pollen season. Higher correlation coefficients are more commonly found between pollen concentrations and meteorological factors observed in the same day than with meteorology from the previous day. The analysis of meteorological conditions and influence of air transport on pollen concentration, spatial distribution of tree species, and impact of air transport on pollen concentration has provided the reasons for the difference in pollen levels at two stations.

Acknowledgements Calculations have been carried out using resources provided by the Wrocław Centre for Networking and Supercomputing (http://wcss.pl), Grant No. 170. This work has been supported by the Polish Ministry of Science and Higher Education Grants No. UMO-2017/25/N/ST10/00494 and UMO2017/25/B/ST10/00926.
Open Access This article is distributed under the terms of the Creative Commons Attribution 4.0 International License (http:// creativecommons.org/licenses/by/4.0/), which permits unrestricted use, distribution, and reproduction in any medium, provided you give appropriate credit to the original author(s) and the source, provide a link to the Creative Commons license, and indicate if changes were made.

\section{References}

Andersen, T. B. (1991). A model to predict the beginning of the pollen season. Grana, 30(1), 269-275. https://doi.org/10. 1080/00173139109427810.

Bilińska, D., Skjøth, C. A., Werner, M., Kryza, M., Malkiewicz, M., Krynicka, J., et al. (2017). Source regions of ragweed pollen arriving in south-western Poland and the influence of meteorological data on the HYSPLIT model results. 
Aerobiologia, 33(3), 315-326. https://doi.org/10.1007/ s10453-017-9471-9.

Bińkowska, I., Szopińska, E., Jaworek, J. \& Wierzcholska, S. (2013). Leksykon zieleni Wroctawia. Wrocław: Via Nova, DC. ISBN 978-83-64025-06-B

Borycka, K., \& Kasprzyk, I. (2018). Do the threats of alder and birch allergenic pollen differ within an urban area? Urban Forestry \& Urban Greening, 34, 281-293. https://doi.org/ 10.1016/j.ufug.2018.07.013.

Cesari, R., Paradisi, P., \& Allegrini, P. (2014). Source identification by a statistical analysis of backward trajectories based on peak pollution events. International Journal of Environment and Pollution, 55(1/2/3/4), 94-103. https:// doi.org/10.1504/IJEP.2014.065909.

Charalampopoulos, A., Lazarina, M., Tsiripidis, I., \& Vokou, D. (2018). Quantifying the relationship between airborne pollen and vegetation in the urban environment. Aerobiologia, 34(3), 285-300. https://doi.org/10.1007/s10453018-9513-y.

Dąbrowska-Zapart, K. (2008). The influence of meteorological factors on the hazel (Corylus L.) pollen concentration in Sosnowiec in the years 1997-2007. Acta Agrobotanica, 61(2), 49-56.

Dąbrowska-Zapart, K., Chłopek, K., \& Niedźwiedź, T. (2018). The impact of meteorological conditions on the concentration of alder pollen in Sosnowiec (Poland) in the years 1997-2017. Aerobiologia. https://doi.org/10.1007/s10453018-9524-8.

Draxler, R. R., \& Hess, G. D. (1998). An overview of the HYSPLIT_4 modelling system for trajectories, dispersion and deposition. Australian Meteorological Magazine, 47(4), 295-308.

Efstathiou, C., Isukpalli, S., \& Georgopoulos, P. (2011). A mechanistic modeling system for estimating large-scale emissions and transport of pollen and co-allergens. Atmospheric Environment, 45, 2260-2276. https://doi.org/10. 1016/j.atmosenv.2010.12.008.

Galán, C., Ariatti, A., Bonini, M., Clot, B., Crouzy, B., Dahl, A., et al. (2017). Recommended terminology for aerobiological studies. Aerobiologia, 33(3), 293-295. https://doi.org/ 10.1007/s10453-017-9496-0.

Galán, C., Smith, M., Thibaudon, M., Frenguelli, G., Clot, B., Gehrig, R., et al. (2014). Pollen monitoring: minimum requirements and reproducibility of analysis. Aerobiologia, 30(4), 385-395. https://doi.org/10.1007/s10453-014-93355.

Godłowska, J., Hajto, M. J., \& Tomaszewska, M. (2015). Spatial analysis of air masses backward trajectories in order to identify distant sources of fine particulate matter emission. Archives of Environmental Protection, 41(2), 28-35. https://doi.org/10.1515/aep-2015-0015.

Gottardini, E., \& Cristofolini, F. (1997). Spring airborne pollen data in two sites in Trentino (Northern Italy): a comparison with meteorological data. Aerobiologia, 13, 199-204.

Helbig, N., Vogel, B., Vogel, H., \& Fiedler, F. (2004). Numerical modelling of pollen dispersion on the regional scale. Aerobiologia, 3, 3-19.

Hirst, J. M. (1952). An automatic volumetric spore trap. Annals of Applied Biology, 39, 257-265.

Jato, V., Rodriguez-Rajo, F. J., Alcazar, P., De Nuntiis, P., \& Galan, C. (2006). May the definition of pollen season influence aerobiological results? Aerobiologia, 22, 13-25. https://doi.org/10.1007/s10453-005-9011-x.

Kasprzyk, I. (2010). Początek sezonów pyłkowych olszy i leszczyny a początek pylenia w różnych warunkach siedliskowych Rzeszowa. Alergoprofil, 6(2), 32-37.

Kasprzyk, I. (2013). The patterns of Corylus and Alnus pollen seasons and pollination periods in two Polish cities located in different climatic regions. Aerobiologia, 29, 495-511. https://doi.org/10.1007/s10453-013-9299-x.

Kryza, M., Dore, A. J., Błaś, M., \& Sobik, M. (2011). Modelling deposition and air concentration of reduced nitrogen in Poland and sensitivity to variability in annual meteorology. Journal of Environmental Management, 92(4), 1225-1236. https://doi.org/10.1016/j.jenvman.2010.12.008.

Kryza, M., Wałaszek, K., Ojrzyńska, H., Szymanowski, M., Werner, M., \& Dore, A. J. (2017). High-resolution dynamical downscaling of ERA-Interim using the WRF Regional Climate Model for the Area of Poland. Part 1: Model configuration and statistical evaluation for the 1981-2010 period. Pure and Applied Geophysics, 174(2), 511-526. https://doi.org/10.1007/s00024-016-1272-5.

Majeed, H. T., Periago, C., Alarcón, M., \& Belmonte, J. (2018). Airborne pollen parameters and their relationship with meteorological variables in NE Iberian Peninsula. Aerobiologia, 34, 375-388. https://doi.org/10.1007/s10453018-9520-z.

Malkiewicz, M., Drzeniecka-Osiadacz, A., \& Krynicka, J. (2016). The dynamics of the Corylus, Alnus and Betula pollen seasons in the context of climate change (SW Poland). Science of the Total Environment, 573, 740-750. https://doi.org/10.1016/j.scitotenv.2016.08.103.

Malkiewicz, M., Klaczak, K., Drzeniecka-Osiadacz, A., Krynicka, J., \& Migała, K. (2014). Types of Artemisia pollen season depending on the weather conditions in Wrocław (Poland), 2002-2011. Aerobiologia, 30(1), 13-23. https:// doi.org/10.1007/s10453-013-9304-4.

Myszkowska, D., Jenner, B., Puc, M., Stach, A., Nowak, M., Malkiewicz, M., et al. (2010). Spatial variations in the dynamics of the Alnus and Corylus pollen seasons in Poland. Aerobiologia, 26(3), 209-221. https://doi.org/10. 1007/s10453-010-9157-z.

Nowosad, J., Stach, A., Kasprzyk, I., Grewling, Ł., Latałowa, M., Puc, M., et al. (2015). Temporal and spatiotemporal autocorrelation of daily concentrations of Alnus, Betula, and Corylus pollen in Poland. Aerobiologia, 31(2), 159-177. https://doi.org/10.1007/s10453-014-9354-2.

Ojrzyńska, H., Kryza, M., Wałaszek, K., Szymanowski, M., Werner, M., \& Dore, A. J. (2017). High-resolution dynamical downscaling of ERA-Interim using the WRF Regional Climate Model for the Area of Poland. Part 2: Model performance with respect to automatically derived circulation types. Pure and Applied Geophysics, 174(2), 527-550. https://doi.org/10.1007/s00024-016-1273-4.

Piotrowska, K., \& Kaszewski, B. M. (2009). The influence of Meteorological condition on the start of the hazel (Corylus L.) pollen season in Lublin, 2001-2009. Acta Agrobotanica, 62(2), 59-66.

Piotrowska-Weryszko, K. (2013). The effect of the meteorological factors on the Alnus pollen season in Lublin (Poland). Grana, 52(3), 221-228. https://doi.org/10.1080/ 00173134.2013 .772653$. 
Puc, M. (2007). The effect of meteorological conditions on hazel (Corylus spp.) and alder (Alnus spp.) pollen concentration in the air of Szczecin. Acta Agrobotanica, 60(2), 65-70.

Puc, M., \& Kasprzyk, I. (2013). The patterns of Corylus and Alnus pollen seasons and pollination periods in two Polish cities located in different climatic regions. Aerobiologia, 29(4), 495-511. https://doi.org/10.1007/s10453-013-9299-x.

Puc, M., Wolski, T., Câmara Camacho, I., Myszkowska, D., Kasprzyk, I., Grewling, Ł., et al. (2015). Fluctuation of birch (Betula L.) pollen seasons in Poland. Acta Agrobotanica, 68(4), 303-313. https://doi.org/10.5586/aa.2015.041.

Rapiejko, P., Stankiewicz, W., Szczygielski, K., \& Jurkiewicz, D. (2007). Threshold pollen count necessary to evoke allergic symptoms. Otolaryngologia Polska, 61(4), 591-594. https:// doi.org/10.1016/S0030-6657(07)70491-2.

Rodriguez-Rajo, F. J., Dopazo, A., \& Jato, V. (2004). Environmental factors affecting the start of pollen season and concentrations of airborne Alnus pollen in two localities of Galicia (NW Spain). Annals of Agricultural and Environmental Medicine, 11, 35-44.

Rojo, J., Rapp, A., Lara, B., Fernández-González, F., \& PérezBadia, R. (2015). Effect of land uses and wind direction on the contribution of local sources to airborne pollen. Science of the Total Environment, 538, 672-682. https://doi.org/10. 1016/j.scitotenv.2015.08.074.

Samoliński, B., Raciborski, F., Lipiec, A., Tomaszewska, A., Krzych-Fałta, E., Samel-Kowalik, P., et al. (2014). Epidemiologia Chorób Alergicznych w Polsce (ECAP). Alergologia Polska, 1(1), 10-18. https://doi.org/10.1016/j. alergo.2014.03.008.
Skjøth, C. A., Bilińska, D., Werner, M., Malkiewicz, M., Adams-Groom, B., Kryza, M., et al. (2015). Footprint areas of pollen from alder (Alnus) and birch (Betula) in the UK (Worcester) and Poland (Wroclaw) during 2005-2014. Acta Agrobotanica. https://doi.org/10.5586/aa.2015.044.

Smith, M., Emberlin, J., \& Kress, A. (2005). Examining high magnitude grass pollen episodes at Worcester, United Kingdom, using back-trajectory analysis. Aerobiologia, 21(2), 85-94. https://doi.org/10.1007/s10453-005-4178-8.

Sofiev, M., Siljamo, P., Ranta, H., Linkosalo, T., Jaeger, S., Rasmussen, A., et al. (2013). A numerical model of birch pollen emission and dispersion in the atmosphere: Description of the emission module. International Journal of Biometeorology, 57(1), 45-58. https://doi.org/10.1007/ s00484-012-0532-z.

Stach, A., Smith, M., Skjøth, C. A., \& Brandt, J. (2007). Examining Ambrosia pollen episodes at Poznań (Poland) using back-trajectory analysis. International Journal of Biometeorology, 51(4), 275-286. https://doi.org/10.1007/ s00484-006-0068-1.

Stępalska, D., Myszkowska, D., Piotrowicz, K., \& Kasprzyk, I. (2016). The phenological phases of flowering and pollen seasons of spring flowering tree taxa against a background of meteorological conditions in Kraków, Poland. Acta Agrobotanica, 69(2), 1678. https://doi.org/10.5586/aa.1678.

Szewczak, P. (2014). Meteorologia dla pilota samolotowego (PPL, CPL, ATPL, IR). Poznań, DC: AVIA-TEST.

Woś, A. (1999). Klimat Polski. Warszawa, DC: Wydawnictwo Naukowe PWN. ISBN 978-83-939482-0-8. 